\title{
Kandungan Klorofil dan Fukosantin serta Pertumbuhan Skeletonema costatum pada Pemberian Spektrum Cahaya yang Berbeda
}

\author{
Rizqi Umi Arifah*, Sri Sedjati, Endang Supriyantini, Ali Ridlo \\ Departemen Ilmu Kelautan, Fakultas Perikanan dan Ilmu Kelautan, Universitas Diponegoro \\ Jl. Prof. Sudarto, SH, Tembalang, Semarang, Jawa Tengah, 50275 \\ Email: rizqiarifah@gmail.com
}

\begin{abstract}
Abstrak
Skeletonema costatum mengandung klorofil-a, klorofil-c, dan fukosantin yang menyebabkan selnya berwarna hijau kecoklatan. Klorofil dan fukosantin memiliki berbagai manfaat, salah satunya dalam bidang kesehatan sebagai anti-bakteri,anti-oksidan, anti-inflamasi, anti-obesitas, anti-diabetes. Cahaya merupakan faktor lingkungan yang dapat mempengaruhi pertumbuhan dan kandungan pigmen pada mikroalga. Penelitian ini bertujuan untuk menentukan spektrum cahaya yang memiliki pengaruh terhadap pertumbuhan, kandungan klorofil dan fukosantin S. costatum. Metode yang digunakan adalah metode eksperimental laboratoris. Diatom $S$. costatum dikultivasi dengan tiga spektrum cahaya yang berbeda yaitu putih, biru, dan merah. Pertumbuhan sel $S$. costatum diamati sampai $2 \times 24$ jam kemudian dipanen untuk perhitungan biomassanya. Biomassa kering hasil kultivasi diekstraksi menggunakan metanol. Kadar pigmen ekstrak metanol dianalisis menggunakan spektrofotometer UV-Vis dan identifikasi pigmen dengan uji Kromatografi Lapis Tipis (KLT). Hasil penelitian menunjukkan bahwa perlakuan cahaya putih secara signifikan meningkatkan kandungan klorofi- a S. Costatum dibandingkan spektrum cahaya merah, namun tidak berbeda nyata terhadap spektrum cahaya biru. Pertumbuhan, kandungan klorofil-c dan fukosantin S. costatum pada pemberian spektrum cahaya yang berbeda tidak menunjukkan perbedaan nyata.
\end{abstract}

Kata kunci : Skeletonema costatum, Spektrum Cahaya, Pertumbuhan, Klorofil, Fukosantin

\section{Abstract}

\section{Chlorophyll and Fucoxanthin Content, Growth of Skeletonema costatum on Different Light Spectrum}

Skeletonema costatum contains chlorophyll-a, chlorophyll-c, and fucoxanthin giving the color of the cells. Chlorophyll and fucoxanthin have various benefits, e.g., in the medical field as anti-bacterial, anti-oxidant, anti-inflammatory, anti-obesity, and anti-diabetes. Light is one of the environmental factors that affects the growth and pigment content of microalgae. This study aims to determine the spectrum of light that influences growth, chlorophyll content, and fucoxanthin of S. costatum. The method used was a laboratory experimental method. Diatom S. costatum was cultivated with three different spectrums of light (white, blue, and red). Growth of S. costatum cells was observed up to $2 \times 24$ hours and then harvested for biomass calculations. Dry biomass was extracted using methanol. Pigment content of the S. costatum methanol extract was analyzed using UV-Vis spectrophotometer and pigments identification using Thin Layer Chromatography (TLC). The results showed that the chlorophyll content of S. costatum under white light spectrum was significantly higher from the red light spectrum, but not substantially different from the blue light spectrum. Growth, chlorophyll-c and fucoxanthin content of S. costatum didn't show significant differences under different light spectra.

Keywords: Skeletonema costatum, Light Spectrum, Growth, Chlorophylls, Fucoxanthin

\section{PENDAHULUAN}

Diatom merupakan mikroalga uniseluler dan eukariotik yang mengandung pigmen dan dapat berfotosintesis. Beberapa diatom dapat hidup secara heterotropik pada keadaan gelap jika terdapat sumber karbon organik yang mencukupi (Round et al., 2007). Diatom memiliki warna coklat keemasan, dengan pigmen yang terkandung di dalam diatom sedikit berbeda dibandingkan dengan pigmen yang terkandung di dalam tanaman dan beberapa alga lainnya. Pigmen yang terkandung di dalam diatom antara lain klorofil-a, klorofil-c dan karotenoid yang terdiri dari betakaroten ( $\beta$-car), fukosantin (Fx), diadinosantin 
(Ddx), diatosantin (Dtx), violasantin (Vx), antherasantin (Ax), dan zeasantin (Zx) (Kuczynska et al., 2015).

Skeletonema costatum merupakan salah satu spesies dari diatom yang mudah ditemukan di perairan. Diatom $S$. costatummemiliki beberapa keunggulan seperti dapat bertahan pada berbagai macam kondisi cahaya dan suhu, mampu memanfaatkan nutrien lebih cepat dibanding mikroalga yang lain, memiliki waktu hidup yang relatif cepat dan memiliki kandungan fukosantin yang tinggi untuk dimanfaatkan. Diatom $S$. costatum biasa dimanfaatkan sebagai pakan hidup bagi udang, lobster, teritip, kerang dan tiram (Kumar dan Prabu, 2014). Diatom S. costatum memiliki warna sel hijau kecoklatan. Pigmen yang terkandung di dalam $S$. costatum adalah klorofil-a, klorofil-c, dan fukosantin (Isnansetyo dan Kurniastuty, 1995).

Pigmen klorofil dan fukosantin memiliki berbagai manfaat yang dapat diaplikasikan dalam kehidupan manusia. Klorofil dapat dimanfaatkan dalam bidang kesehatan yaitu sebagai antianemia, anti-proteolitik, anti-bakteri,anti-oksidan, meningkatkan immunitas,menstabilkan tekanan darah, memperbaiki fungsi hati, dan menyembuhkan luka (Limantara dan Rahayu, 2008). Fukosantin telah banyak diteliti pemanfaatannya sebagai salah satu suplemen makanan yang aman dikonsumsi oleh manusia. Beberapa manfaat dari fukosantin yaitu digunakan sebagai anti-inflamasi, anti-tumor, anti-obesitas, anti-diabetes, anti-malaria dan berbagai macam aktivitas fisiologi lainnya (Li et al., 2018).

Spektrum cahaya tampak yang diserap pada saat terjadinya proses fotosintesis yaitu antara warna ungu pada panjang gelombang $380 \mathrm{~nm}$ sampai warna merah pada panjang gelombang 750 nm. Energi yang digunakan pada proses fotosintesis adalah dalam bentuk foton yang berasal dari spektrum cahaya tersebut. Energi berbanding terbalik dengan panjang gelombang. Energi dari spektrum cahaya biru lebih kuat dibandingkan dengan spektrum cahaya merah. Selama proses fotosintesis spektrum cahaya biru dengan panjang gelombang 400-500 $\mathrm{nm}$ diserap maksimal oleh karotenoid, sedangkan spektrum cahaya merah yang memiliki panjang gelombang 600-700 nm diserap maksimal oleh klorofil (Richmond, 2004).

Penelitan tentang pertumbuhan dan kandungan pigmen dengan pemberian spektrum cahaya telah diteliti untuk beberapa spesies mikroalga, namun untuk $S$. costatum belum pernah dilakukan. Menurut Asuthkar et al. (2016), pertumbuhan Chlorella pyrenoidosa tertinggi terjadi pada pemberian spektrum cahaya biru. Pemberian spektrum cahaya merah menghasilkan pertumbuhan paling rendah dibandingkan dengan spektrum cahaya biru, putih dan hijau. Hal tersebut disebabkan karena energi pada spektrum cahaya biru lebih besar dibandingkan dengan spektrum cahaya merah. Menurut Suyono et al. (2015), kandungan klorofil S. costatum meningkat 3 kali lipat pada pemberian spektrum cahaya merah dengan sinar UV dan meningkat 4 kali lipat dengan pemberian spektrum cahaya biru sinar UV, sedangkankandungan karotenoid meningkat dengan adanya pemberian kombinasi spektrum cahaya biru dengan sinar UV.

Pada penelitian ini diharapkan pemberian perlakuan spektrum cahaya yang berbeda, yaitu putih, biru dan merah dapat memberikan pengaruh yang optimal terhadap peningkatan kandungan klorofil dan fukosantin serta pertumbuhan $S$. costatum.

\section{MATERI DAN METODE}

Metode penelitian yang digunakan adalah metode eksperimental laboratoris. Metode eksperimen adalah cara untuk menguji apakah variabel-variabel eksperimen efektif atau tidak. Variabel kontrol diperlukan untuk menguji keefektifan dalam penelitian tersebut. Penelitian eksperimen bertujuan untuk menguji hipotesis yang telah dirumuskan (Suryana, 2010).

Rancangan penelitian ini adalah Rancangan Acak Kelompok (RAK). Perlakuan yang diberikan adalah pemberian spectrum cahaya yang berbeda.Sumber cahaya dihasilkan dari lampu LED 17 watt yang dilapisi mika bening berwarna putih, biru, dan merah dengan ketebalan 0,25 mm. Pada setiap perlakuan spektrum cahaya dilakukan pengulangan sebanyak tiga kali.

Media kultivasi terdiri dari air laut steril yang telah ditambahkan pupuk sebagai nutrien bagi mikroalga yang akan dikultivasi. Air laut yang telah disterilkan memiliki salinitas awal sebesar 35\% sedangkan $S$. costatum dapat tumbuh secara optimal pada salinitas $25-29 \%$. Penurunan salinitas dilakukan dengan mengencerkan air laut steril menggunakan air tawar. Menurut Arrokhman et al. (2012). Salinitas air laut steril yang dihasilkan dari proses pengenceran adalah $27 \%$.

Komposisi pupuk untuk kultur Skeletonema costatum adalah mengacu pada BBPBAP,Jepara sebagai berikut: Natrium dihidrofosfat $\left(\mathrm{NaH}_{2} \mathrm{PO}_{4}\right)$ $15 \mathrm{ppm}, \mathrm{KNO}_{3} 100 \mathrm{ppm}, \mathrm{Na}_{2} \mathrm{SiO}_{3} 10$ ppm, EDTA 5 ppm, dan $\mathrm{FeCl}_{3} 1 \mathrm{ppm}$. Masing-masing 
komposisi dari pupuk tersebut ditambahkan sebanyak $0,5 \mathrm{ml}$ ke dalam 1 liter air laut steril yang akan digunakan sebagai media kultivasi.

\section{Kultivasi S. costatum}

Proses kultivasi dilakukan pada suatu ruang kultivasi dengan suhu $20^{\circ} \mathrm{C}$ (Tjahjo et al., 2002). Wadah untuk kultivasi menggunakan 9 buah akuarium berkapasitas 3 liter dan total volume kultivasi adalah2 liter $(1500 \mathrm{ml}$ media air laut steril dan $500 \mathrm{ml}$ bibit $S$. costatum). Masingmasing komposisi pupuk ditambahkan sebanyak 1 $\mathrm{ml}$ ke dalam media kultivasi untuk volume kultivasi 2 liter, selanjutnya dilakukan aerasi agar air laut dan pupuk menjadi homogen. Setelah homogen, bibit $S$. costatum sebanyak $500 \mathrm{ml}$ ditambahkan ke dalam media kultivasi dan tetap dilakukan aerasi dengan kecepatan sedang. Pada setiap ruang kultivasi diberi satu sumber cahaya berbeda yang berasal dari lampu LED 17 watt setara dengan 731,98 Lux. Sumber cahaya yang digunakan yaitu warna putih, merah, dan biru. Penyinaran dan pemberian aerasi dilakukan selama masa kultivasi berlangsung ( $2 \times 24$ jam). Kultivasi dengan pemberian spektrum cahaya berbeda dilakukan secara berulang-ulang sehingga mendapatkan biomassa kering $S$. costatum sebanyak 1 gram.

Pengamatan pertumbuhan dilakukan setiap 24 jam sekali selama kultivasi berlangsung ( $2 \times 24$ jam) dengan menghitung jumlah sel dari $S$. costatum hasil dari kultivasi. Perhitungan jumlah sel mikroalga dilakukan sebanyak tiga kali pada setiap akuarium kultivasi. Mikroalga S. costatum diambil menggunakan pipet sebanyak $2 \mathrm{ml}$ kemudian dimasukkan ke dalam vial untuk selanjutnya dihitung kepadatan selnya(Armanda, 2013). Perhitungan jumlah sel dilakukan pada bilik Haemocytometer Improved Neubauer di bawah mikroskop (perbesaran 10x10) dengan bantuan handy counter yang berfungsi untuk menghitung jumlah sel (Andersen, 2005)

\section{Pemanenan S. costatum}

Diatom S. costatum tumbuh dengan waktu yang relatif singkat. Menurut Armanda (2013), fase eksponensial pada $S$. costatum terjadi pada hari kedua atau setelah dikultivasi selama $2 \times 24$ jam. Pada fase ini jumlah sel mengalami peningkatan secara cepat. Pemanenan $S$. costatum dilakukan pada saat fase eksponensial. Pemanenan dilakukan dengan cara mengendapkan hasil kultivasi $S$. costatum di dalam akuarium selama \pm 2 jam. Air laut hasil pengendapan yang telah terpisah dari $S$. costatum dibuang terlebih dahulu.
Diatom $S$. costatum yang mengendap di bagian bawah akuarium kemudian disaring menggunakan kertas whatmann no. 42 untuk memisahkan antara mikroalga dengan air laut yang masih tersisa. Hasil penyaringan berupa endapan $S$. costatum yang berada pada kertas saring kemudian dipindahkan ke dalam cawan petri. Diatom $S$. costatum yang berada pada cawan petri dikeringkan pada suhu kamar pada kisaran suhu $27^{\circ} \mathrm{C}$ selama \pm 2 hari, kemudian ditimbang untuk mengetahui berat biomassa kering.

\section{Ekstraksi S. costatum}

Ekstraksi dilakukan dengan metode maserasi dengan menggunakan pelarut metanol p.a. Proses ektraksi S. costatum dilakukan dengan perbandingan 1:20 yaitu dengan cara mencampur 1 gram $S$. costatum yang sudah kering dengan 20 $\mathrm{ml}$ metanol. Sampel kemudian dimaserasi selama 24 jam. Sampel yang telah dimaserasi disaring menggunakan kertas saring Whatman no. 42, filtrat yang diperoleh disentrifugasi dengan kecepatan 3000 rpm selama 30 menit untuk memisahkan residu (Sedjati dan Yudiati, 2012).

\section{Pembuatan Pola Spektra UV-Vis Filtrat S. costatum}

Pembuatan pola spektra dilakukan untuk mengetahui puncak (peak) pada suatu sampel yang dihasilkan pada spektrum suatu unsur tertentu pada panjang gelombang tertentu. Filtrat hasil ekstraksi metanol yang masih pekat harus diencerkan terlebih dahulu agar nilai absorbansi filtrat berada pada kisaran 0,2-0,8. Pengenceran larutan sampel dilakukan dengan perbandingan 1:9, yaitu dengan mengambil $1 \mathrm{ml}$ ekstrak pekat kemudian dilarutkan ke dalam $9 \mathrm{ml}$ pelarut methanol p.a. Filtrat ekstrak $S$. costatum yang telah diencerkan dibuat pola spektranya dengan memasukan sebanyak $4 \mathrm{ml}$ filtrat ke dalam cuvet, kemudian diukur dengan menggunakan spektrofotometer UV-Vis pada panjang gelombang 400-800 $\mathrm{nm}$.

\section{Analisis Kadar Pigmen Klorofil dan Fukosantin}

Analisis kadar pigmen klorofil dan fukosantin dilakukan secara kuantitatif. Filtrat ekstrak $S$. costatum yang telah diencerkan dengan perbandingan 1:9 diukur absorbansinya menggunakan spektrofotometer UV-Vis. Pengukuran absorbansi dilakukan untuk mengetahui kandungan pigmen di dalam diatom $S$. costatum berdasarkan panjang gelombang yang diserap oleh pigmen klorofil dan fukosantin. Absorbansi filtrat diukur pada panjang gelombang 
$470 \mathrm{~nm}, 581 \mathrm{~nm}, 630 \mathrm{~nm}, 631 \mathrm{~nm}$, dan $664 \mathrm{~nm}$. Absorbansi dicatat dan dimasukkan ke dalam rumus untuk mengetahui kandungan pigmen.Kandungan pigmen klorofil dihitung menggunakan rumus menurut Gao et al. (2018).

\section{Analisis Pigmen Klorofil dan Fukosantin}

Analisis pigmen secara kualitatif dilakukan dengan menggunakan Kromatografi Lapis Tipis (KLT). Plat silika gel dipilih sebagai fase diam. Fase gerak yang digunakan adalah kloroform : etanol dengan perbandingan 98:2 (v/v) (Dimara et al., 2012). Komposisi fase gerak tersebut dipilih karena dapat memisahkan komponen pada filtrat ekstrak metanol $S$. costatum dengan baik.

Eluen dimasukkan ke dalam gelas beaker. Kertas saring dimasukkan untuk mempercepat proses penjenuhan kemudian ditutup menggunakan alumunium foil. Plat silika gel yang digunakan yaitu berukuran $1 \times 5 \mathrm{~cm}$, kemudian diberi tanda $1 \mathrm{~cm}$ dari dasar plat sebagai tempat penotolan sampel dan $0,5 \mathrm{~cm}$ dari ujung atas plat sebagai batas eluen. Filtrat ekstrak $S$. costatum hasil maserasi yang masih pekat ditotolkan pada plat silika gel menggunakan mikropipet sebanyak $10 \mu \mathrm{l}$ pada jarak $1 \mathrm{~cm}$ dari dasar plat. Plat kemudian dimasukkan ke dalam gelas beaker dan diposisikan berhadapan dengan kertas saring.

Eluen akan diserap oleh plat kemudian akan terbentuk beberapa komponen pada plat tersebut. Plat dikeluarkan dari gelas beaker ketika eluen sudah mencapai titik batas eluen. Komponen yang terbentuk pada plat kemudian dianalisis berdasarkan warna dan penentuan nilai faktor retardasi (Rf). Perrhitungan nilai Rf dapat menggunakan rumus menurut Dimara et al. (2012).

\section{Analisis Data}

Analisis data bertujuan untuk mengetahui pengaruh pemberian spektrum cahaya yang berbeda terhadap pertumbuhan, kandungan klorofil dan fukosantin S. costatum. Data yang diperoleh dianalisis menggunakan software SPSS. Data pada setiap perlakuan dilakukan uji normalitas, apabila memenuhi kemudian dilakukan uji homogenitas varian (uji Levene, $\mathrm{p}>0,05)$. Repeated measures ANOVA digunakan untuk analisis data pertumbuhan $S$. costatum (Peckarsky et al., 2013).

One-wayMultivariate

ANOVA

(MANOVA) digunakan untuk analisis data pengaruh pemberian spektrum cahaya yang berbeda terhadap kandungan pigmen klorofil dan fukosantin $S$. costatum dengan tingkat kepercayaan 95\%. Uji normalitas dan uji homogenitas dilakukan terlebih dahulu sebelum menganalis menggunakan MANOVA. Berdasarkan analisis tersebut apabila perlakuan yang diberikan memberikan hasil beda nyata maka dilanjutkan dengan uji lanjutan menggunakan Tukey HSD dengan taraf signifikan $5 \%$ untuk mengetahui perbedaan antar perlakuan (Saura et al., 2012).

\section{HASIL DAN PEMBAHASAN}

Kultivasi $S$. costatum dilakukan selama $2 \times 24$ jam dengan tiga perlakuan pemberian spectrum cahaya berbeda. Laju pertumbuhan $S$. costatum disajikan pada Gambar 1. Berdasarkan Gambar 1 diketahui bahwa jumlah sel $S$. costatum bertambah setiap harinya. Jumlah sel $S$. costatum di hari kedua pada perlakuan spectrum cahaya putih, biru, dan merah berturut-turut yaitu sebesar $109.600 \mathrm{sel} / \mathrm{ml}, 118.000 \mathrm{sel} / \mathrm{ml}$, dan 110.800 $\mathrm{sel} / \mathrm{ml}$. Berdasarkan hasil dari uji repeated measures ANOVA, perlakuan pemberian spectrum cahaya yang berbeda terhadap pertumbuhan tidak menunjukkan perbedaan nyata ( $>0,05)$. Perlakuan pemberian spektrum cahaya yang berbeda tidak berpengaruh terhadap laju pertumbuhan $S$. costatum.

Pertumbuhan mikroalga dipengaruhi oleh beberapa faktor antara lain cahaya, salinitas, suhu, $\mathrm{pH}$, tekanan osmosis dan nutrisi. Cahaya memiliki peranan penting dalam pertumbuhan karena cahaya dibutuhkan dalam proses fotosintesis. Cahaya yang dimaksud adalah cahaya tampak yang terdiri dari tujuh spektrum cahaya dengan panjang gelombang antara 380-750 nm (Richmond, 2004). Spektrum cahaya yang digunakan adalah spektrum cahaya putih, biru, dan merah.Setiap spektrum cahaya memiliki panjang gelombang tertentu dimana panjang gelombang pada spektrum cahaya ini dimanfaatkan dalam proses fotosintesis.

Spektrum cahaya biru yang diberikan pada kultivasi $S$. costatum menunjukkan kepadatan sel tertinggi dibandingkan dengan dua spektrum cahaya lainnya. Setiap spektrum cahaya memilikipanjang gelombang, di mana panjang gelombang ini berkaitan dengan energi yang dihasilkan oleh spektrum cahaya tersebut. Energi ini berkaitan dengan panjang gelombang yang dihasilkan oleh masing-masing spektrum cahaya. Spektrum cahaya biru memiliki panjang gelombang yang pendek, namun memiliki energi yang lebih besar dibandingkan dengan energi yang dihasilkan oleh spektrum cahaya merah yang memiliki panjang gelombang lebih besar. Energi 


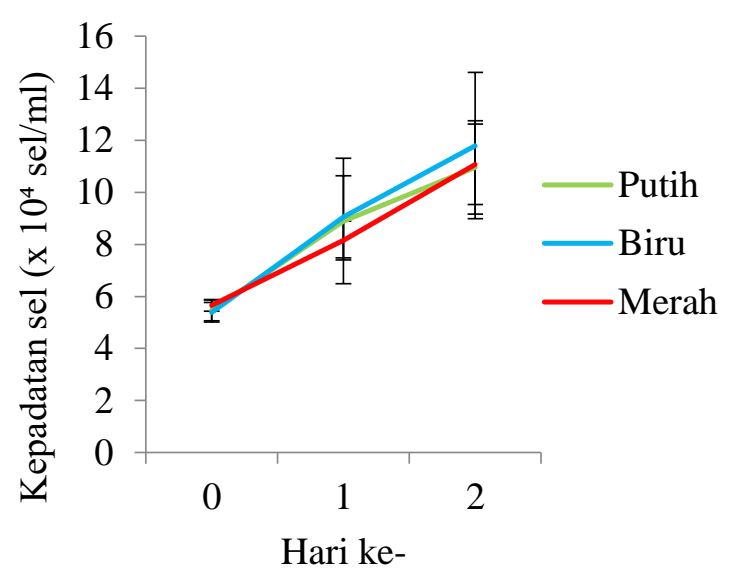

Gambar 1. Laju Pertumbuhan S.costatum

yang lebih besar akan menggerakkan proses fotosintesis dengan lebih baik sehingga akan terjadi peningkatan pertumbuhan.

Pigmen utama yang berperan dalam proses fotosintesis adalah klorofil-a dan terdapat beberapa pigmen asesori yang membantu dalam proses fotosintesis di dalam $S$. costatum yaitu klorofil-c dan fukosantin. Menurut Kuczynska et al. (2015), spektrum cahaya biru memiliki pengaruh yang signifikan terhadap diatom yaitu menghasilkan kepadatan sel yang lebih banyak daripada fotosintesis yang terjadi pada saat pemberian spektrum cahaya putih. Pada perlakuan pemberian spektrum cahaya biru dan merah hanya ada satu kisaran panjang gelombang yang berperan dalam fotosintesis.

\section{Analisis Kadar Klorofil-a, Klorofil-c dan Fukosantin pada Ekstrak S. costatum dengan Spektrofotometer UV-Vis}

Kandungan klorofil-a dengan pemberian spectrum cahaya putih berbeda nyata $(p<0,05)$ dengan spektrum cahaya merah, tetapi tidak menunjukkan perbedaan nyata $(p>0,05)$ dengan spektrum cahaya biru (Tabel 1). Pemberian spektrum cahaya biru tidak berbeda nyata $(p>0,05)$ dengan pemberian spektrum cahaya merah. Klorofil-a tertinggi dihasilkan pada perlakuan pemberian spektrum cahaya putih, ini dikarenakan cahaya putih memiliki panjang gelombang yang lebih banyak yaitu antara 380$760 \mathrm{~nm}$. Panjang gelombang yang dimiliki oleh spektrum cahaya putih dapat memenuhi kekurangan pada panjang gelombang lainnya. Spektrum cahaya putih merupakan gabungan dari tujuh spektrum cahaya. Spektrum cahaya biru dan merah termasuk dari bagian dalam spektrum cahaya putih. Perbedaan nyata terjadi antara spektrum cahaya putih dan merah karena spektrum cahaya merah memiliki panjang gelombang yang diserap secara maksimal oleh klorofil-a. Menurut Richmond(2004), klorofil-a memiliki dua puncak gelombang yaitu terdapat pada spektrum cahaya biru $(450-475 \mathrm{~nm})$ dan spektrum cahaya merah $(630-675 \mathrm{~nm})$. Puncak gelombang pada spektrum cahaya merah lebih tinggi dibandingkan spektrum cahaya biru, sehingga klorofil-a lebih maksimal dalam menyerap spektrum cahaya merah.

Selama proses fotosintesis berlangsung klorofil akan meneruskan spektrum cahaya yang diterimanya. Spektrum cahaya putih memiliki panjang gelombang yang lebih bervariasi sehingga setiap spektrum cahaya saling berpengaruh dan menjaga produksi klorofil menjadi lebih maksimal. Setiap mikroalga memiliki kemampuan yang berbeda dalam menyerap cahaya untuk pembentukan klorofil (Mercado et al., 2004).

Kandungan klorofil-c dan fukosantin pada perlakuan spektrum cahaya yang berbeda tidak menunjukkan perbedaan nyata $(p>0,05)$. Hal tersebut bisa disebabkan karena $S$. costatum masih mampu beradaptasi dengan baik pada perlakuan spektrum cahaya yang diberikan. Klorofil c dan fukosantin sebagai pigmen asesori berperan dalam penyerapan cahaya kemudian menyalurkannya ke klorofil-a. Ketersediaan klorofil-a membuat kandungan klorofil-c dan fukosantin tidak mengalami peningkatan. Klorofil $\mathrm{c}$ dan fukosantinakan meningkat apabila klorofil-a mengalami penurunan dan tidak mampu melakukan proses fotosintesis, sehingga klorofil-c dan fukosantin akan menggantikan klorofil-a untuk melakukan proses fotosintesis. Pemanenan $S$. costatum dilakukan pada saat fase eksponensial, di mana persediaan nutrisi bagi $S$. costatum masih terpenuhi dan jumlah sel terus meningkat. Salah satu unsur yang terkandung di dalam mikroalga adalah nitrogen. Pada fase eksponensial jumlah nitrogen masih mencukupi sehingga klorofil-a masih dalam kondisi normal dan dapat terus melakukan fotosintesis, sedangkan klorofil-c dan fukosantin hanya akan membantu dalam penyerapan cahaya tanpa meningkatkan jumlah pigmennya. Menurut Benavente-Valdes et al. (2016), jika jumlah nitrogen mulai terbatas maka akan mempengaruhi proses fotosintesis. Klorofil-a merupakan senyawa yang kaya akan nitrogen. Pada saat nitrogen di dalam media habis maka klorofil-a akan berfungsi sebagai sumber nitrogen intraseluler untuk mendukung pertumbuhan sel dan produksi biomassa. Klorofil-a jumlahnya akan semakin berkurang karena unsur-unsur lain 
Tabel 1. Kadar Pigmen Ekstrak Metanol S. costatum $(\overline{\mathrm{x}} \pm \mathrm{SD}, \mathrm{n}=3)$

\begin{tabular}{cccc}
\hline \multirow{2}{*}{$\begin{array}{c}\text { Perlakuan } \\
\text { Spektrum Cahaya }\end{array}$} & $\begin{array}{c}\text { Klorofil-a } \\
(\mu \mathrm{g} / \mathrm{g})\end{array}$ & $\begin{array}{c}\text { Klorofil-c } \\
(\mu \mathrm{g} / \mathrm{g})\end{array}$ & $\begin{array}{c}\text { Fukosantin } \\
(\mu \mathrm{g} / \mathrm{g})\end{array}$ \\
\cline { 2 - 4 } & $2.935 \pm 219,58$ & $92,25 \pm 66,54$ & $0,62 \pm 0,08$ \\
Putih & $2.481 \pm 256,95$ & $172,00 \pm 10,48$ & $0,63 \pm 0,09$ \\
Biru & $2.399 \pm 66,22$ & $153,63 \pm 14,13$ & $0,55 \pm 0,02$ \\
\hline
\end{tabular}

Tabel 2. Kisaran Nila Rf, Warna dan Jenis Pigmen S. costatum pada Ekstrak Metanol

\begin{tabular}{|c|c|c|c|c|c|}
\hline Perlakuan & Jumlah Spot & $\mathrm{R}_{\mathrm{f}}$ & Warna & Jenis Pigmen & Pustaka \\
\hline \multirow{7}{*}{ Putih } & \multirow{7}{*}{7} & 0,93 & Jingga & Karoten & 0,88-0,93 (Britton et al., 1995) \\
\hline & & 0,85 & Abu-abu & Feofitin-a & 0,84-0,89 (Jeffrey, 1974) \\
\hline & & 0,78 & Hijau & Klorofil-a & 0,76-0,88 (Jeffrey, 1974) \\
\hline & & 0,65 & Hijau & Klorofil-a & 0,40-0,65 (Britton et al., 1995) \\
\hline & & 0,35 & Kuning & Fukosantin & 0,28-0,49 (Jeffrey, 1961) \\
\hline & & 0,18 & Abu-abu & Pheoporbide-a & 0,07-0,33 (Jeffrey, 1974) \\
\hline & & 0,10 & Hijau & Klorofil-c & 0,01-0,20 (Jeffrey, 1974) \\
\hline \multirow{7}{*}{ Biru } & \multirow{7}{*}{7} & 0,97 & Jingga & Karoten & 0,95-0,97 (Jeffrey, 1974) \\
\hline & & 0,89 & Abu-abu & Feofitin-a & 0,84-0,89 (Jeffrey, 1974) \\
\hline & & 0,84 & Hijau & Klorofil-a & 0,76-0,88 (Jeffrey, 1974) \\
\hline & & 0,76 & Hijau & Klorofil-a & 0,76-0,88 (Jeffrey, 1974) \\
\hline & & 0,52 & Kuning & Fukosantin & 0,42-0,57 (Jeffrey, 1974) \\
\hline & & 0,23 & Abu-abu & Pheoporbide-a & 0,07-0,33 (Jeffrey, 1974) \\
\hline & & 0,05 & Hijau & Klorofil-c & 0,01-0,20 (Jeffrey, 1974) \\
\hline \multirow{7}{*}{ Merah } & \multirow{7}{*}{7} & 0,95 & Jingga & Karoten & 0,95-0,97 (Jeffrey, 1974) \\
\hline & & 0,88 & Abu-abu & Feofitin-a & 0,84-0,89 (Jeffrey, 1974) \\
\hline & & 0,80 & Hijau & Klorofil-a & 0,76-0,88 (Jeffrey, 1974) \\
\hline & & 0,74 & Hijau & Klorofil-a & 0,74-0,84 (Jeffrey, 1961) \\
\hline & & 0,54 & Kuning & Fukosantin & 0,42-0,57 (Jeffrey, 1974) \\
\hline & & 0,33 & Abu-abu & Pheoporbide-a & 0,07-0,33 (Jeffrey, 1974) \\
\hline & & 0,14 & Hijau & Klorofil-c & 0,01-0,20 (Jeffrey, 1974) \\
\hline
\end{tabular}

memanfaatkan nitrogennya, maka pigmen asesori seperti klorofil-c dan fukosantin jumlahnya akan meningkat dengan tujuan mengurangi efisiensi pengumpulan energi karena hilangnya klorofil-a.

\section{Uji Kromatografi Lapis Tipis}

Identifikasi kandungan pigmen di dalam mikroalga $S$. costatum dilakukan dengan menggunakan Kromatografi Lapis Tipis (KLT) dengan plat silikagelsebagai fase diam. Fase gerak yang digunakan yaitu kloroform : etanol (98:2, v/v) (Dimara et al., 2012).Warna yang dihasilkan dihitung nilai $\mathrm{Rf}$ nya untuk pendugaan jenis pigmen yang terkandung di dalam ekstrak. (Tabel 2).

Berdasarkan hasil analisis komposisi pigmen menggunakan metode KLT pada ekstrak metanol S. Costatum terbentuk tujuh spot yang terdiri dari 6 pigmen yang dapat teridentifikasi yaitu klorofi-a, klorofil-c, fukosantin, karoten, feofitin-a, dan pheoporbide-a Pada perlakuan pemberian spektrum cahaya yang berbeda 
menunjukkan spot yang memiliki warna dan nilai Rf yang hampir sama.

Hasil ini berdasarkan penelitian Jeffrey (1974) di mana kisaran nilai Rf karoten (jingga) 0,95-0,97; Rf klorofil-a (hijau) 0,76-0,88; Rf fukosantin (kuning) 0,42-0,57; Rf feofitin-a (abuabu) 0,84-0,89; Rf pheoporbide-a (abu-abu) 0,070,33; dan Rf klorofil c (hijau) 0-0,20. Penelitian yang dilakukan oleh Britton et al. (1995) menunjukkan hasil nilai Rf karoten 0,88-0,93; Rf zantofil 0,10-0,30; Rf feofitin a (abu-abu) 0,760,89; dan Rf klorofil-a (hijau) 0,40-0,65. Penelitian yang dilakukan Jeffrey (1961) menunjukkan bahwa fukosantin memiliki nilai Rf pada kisaran 0,28-0,49; Rf klorofil- a pada kisaran 0,74-0,84. Fase diam yang digunakan sama sedangkan fase gerak yang digunakan dalam penelitian ini adalah kloroform : etanol (v/v). Meskipun fase gerak yang digunakan memiliki komposisi yang berbeda, akan tetapi dominansi kepolaran pada eluen yang digunakan sama-sama kuat.

\section{KESIMPULAN}

Spektrum cahaya yang berbeda tidak menunjukkan perbedaan nyata terhadap pertumbuhan $S$. costatum. Kandungan klorofil-a $S$. costatum pada pemberian spektrum cahaya putih berbeda nyata terhadap spektrum cahaya merah, namun tidak berbeda nyata terhadap spektrum cahaya biru. Kandungan klorofil-c dan fukosantin $S$. costatum pada pemberian spektrum cahaya yang berbeda tidak berbeda nyata.Spektrum cahaya yang paling optimal dalam menghasilkan klorofil-a pada $S$. costatum adalah spektrum cahaya putih. Panjang gelombang dari cahaya yang diserap oleh $S$. Costatum menyebabkan komposisi pigmennya berbeda.

\section{DAFTAR PUSTAKA}

Andersen, R.A. 2005. Algal Culturing Techniques. Elsevier Academic Press., UK, $578 \mathrm{p}$

Armanda, D.T. 2013. Pertumbuhan Kultur Mikroalga Diatom Skeletonema costatum (Greville) Cleve Isolat Jepara pada Medium F/2dan Medium Conway. Bioma. 2(1):49-63.

Arrokhman, S., Abdulgani, N. \& Hidayati, D. 2012. Survival Ratelkan Bawal Bintang (Trachinotus blochii) dalam Media Pemeliharaan Menggunakan Rekayasa Salinitas. Jurnal Sains dan Seni ITS, 1(1):3235 .
Asuthkar, M., Gunti, Y., Rao, R., Rao, C.S. \&Yadavalli, R., 2016. Effect of different wavelengths of light on the growth of Chlorella pyrenoidosa. International Journal of Pharmaceutical Sciences and Research, 7(2):847-51.

Benavente-Valdés, J.R., Aguilar, C., ContrerasEsquivel, J.C., Méndez-Zavala, A. \&Montañez, J., 2016. Strategies to enhance the production of photosynthetic pigments and lipids in chlorophycae species. Biotechnology Reports, 10:117-125.

Britton, G., Jensen, S.L\&Pfander, H. 1995. Carotenoids (IA): Isolation and Analysis. Birkhauser Verlag, Switzerland, $647 \mathrm{p}$.

Dimara, L., Tuririday, H., Tien, D.\& Yenusi, N.B. 2012. Identifikasi dan Fotodegradasi Pigmen Klorofil Rumput Laut Caulerpa racemosa (Forsskal) J. Agardh. Jurnal Biologi Papua, 4(2):47-53.

Gao, G., Xia, J., Yu, J. and Zeng, X., 2018. Physiological response of a red tide alga (Skeletonema costatum) to nitrate enrichment, with special reference to inorganic carbon acquisition. Marine environmental research, 133:15-23.

Isnansetyo, A. \& Kurniastuty. 1995. Teknik Kultur Phytoplankton dan Zooplankton. Kanisius, Yogyakarta, $116 \mathrm{hlm}$.

Jeffrey, S.W. 1961. Paper-Chromatographic Separation of Chlorophylls and Carotenoid from Marine Algae. Biochem J., 80:336-342.

1974. Profiles of Photosynthetic Pigments in the Ocean Using Thin Layer Chromatography. Mar. Biol., 26:101-110.

Kuczynska, P., Jemiola-Rzeminska, M.\& Strzalka, K. 2015. Photosynthetic Pigments in Diatoms. Marine Drugs, 13(9):5847-5881.

Kumar, C.S. \& Prabu, V.A. 2014. Original Research Article Culture of the Phytoplankton Skeletonema costatum Cleve, 1873. International Journal of Current Microbiology and Applied Sciences. 3(11):129-136.

Wang, L.J., Fan, Y., Parsons, R., Hu, G.R., Zhang, P.Y. \& Li, F.L., 2018. A Rapid Method for the Determination of Fucoxanthin in Diatom. Marine drugs, 16(1):1-33.

Limantara, L. \& Rahayu, P. 2008. Sains dan Teknologi Pigmen Alami. Prosiding Seminar Nasional Pigmen 2007 MB UKSW, Salatiga, 16(4):979-1098.

Mercado, J.M., delPilar Sánchez-Saavedra, M., Correa-Reyes, G., Lubián, L., Montero, O. \& Figueroa, F.L., 2004. Blue light effect on 
growth, light absorption characteristics and photosynthesis of five benthic diatom strains. Aquatic Botany, 78(3):265-277.

Peckarsky, B.L., McIntosh, A.R., Álvarez, M. \&Moslemi, J.M., 2013. Nutrient limitation controls the strength of behavioral trophic cascades in high elevation streams. Ecosphere, 4(9):1-17.

Richmond, A. 2004. Handbook of Microalgal Culture: Biotechnology and Applied Phycology. Blackwell Science Ltd., Oxford, $566 \mathrm{p}$.

Round, F.E., Crawford, R.M. \& Mann, D.G. 2007. The Diatoms: Biology and Morphology of the Genera. Cambridge University Press, London, $747 \mathrm{p}$.

Saura, M., Rivas, M.J., Diz, A.P., Caballero, A. \& Rolan-Alvarez, E., 2012. Dietary effects on shell growth and shape in an intertidal marine snail, Littorina saxatilis. Journal of molluscan studies, 78(2):213-216..
Sedjati, S. \& Yudiati, E.. 2012. Profil Pigmen Polar dan Non Polar Mikroalga Laut Spirulina sp. dan Potensinya sebagai Pewarna Alami. Ilmu Kelautan. 17(3):176181.

Suryana. 2010. Metodologi Penelitian Model Praktis Penelitian Kuantitatif dan Kualitatif.UPI, Bandung. 58 hlm.

Suyono, E.A., Pradani, L., Mu'avatun, U., Habiba, R.N. and Rohma, E.F., 2015. Combination of blue, red, white, and ultraviolet lights for increasing carotenoids and biomass of Microalga Haematococcus pluvialis. Procedia Environmental Sciences, 28:399-405.

Tjahjo, W., Erawati, L. \& Hanung, S. 2002. Biologi Fitoplankton. Budidaya Fitoplankton dan Zooplankton. (Prosiding) Proyek Pengembangan Perekayasaan Teknologi Balai Budidaya Laut Lampung. Hal. 3-23. 